\title{
Perbaikan performa reproduksi ikan komet (Carassius auratus auratus Linnaeus 1758) melalui pemberian tepung otak sapi sebagai GnRH alami
}

[Improvement of reproductive performance comet fish (Carassius auratus auratus Linnaeus 1758) through the provision of meal cow's brain as a natural GnRH]

\author{
Ujang Subhan $^{1 \bowtie,}$ Yuli Andriani $^{1}$, Kiki Haetami ${ }^{1}$, Rosidah $^{1}$ Abi Muhamad Abdillah ${ }^{2}$ \\ ${ }^{1}$ Fakultas Perikanan dan Ilmu Kelautan Universitas Padjadjaran \\ Jln. Raya Jatinangor Km 21, Sumedang 45363 \\ ${ }^{2}$ Alumnus Fakultas Perikanan dan Ilmu Kelautan Universitas Padjadjaran
}

Diterima: 09 Maret 2017; Disetujui: 03 Oktober 2017

\begin{abstract}
Abstrak
Penelitian ini bertujuan untuk menentukan dosis tepung otak sapi pada pakan yang berpengaruh terhadap performa telur dan fekunditas ikan komet. Penelitian dilaksanakan di panti benih Fakultas Perikanan dan Ilmu Kelautan Universitas Padjadjaran pada bulan November 2014 sampai dengan Januari 2015. Pengeringan beku otak sapi dilakukan di Pusat Penelitian AntarUniversitas Institut Teknologi Bandung. Penelitian ini menggunakan metode eksperimental dengan Rancangan Acak Lengkap yang terdiri atas 4 perlakuan dan 3 ulangan. Perlakuan yang diberikan yaitu $20 \mathrm{mg} \mathrm{kg}^{-1}$ induk, $35 \mathrm{mg} \mathrm{kg}^{-1}$ induk, $50 \mathrm{mg} \mathrm{kg}^{-1}$ induk dan perlakuan kontrol. Parameter yang diamati yaitu sebaran telur, diameter telur, dan fekunditas relatif menggunakan metode gravimetrik. Data dianalisis menggunakan analisis keragaman dengan uji $\mathrm{F}$ untuk mengetahui pengaruh dari setiap perlakuan. Apabila terdapat perbedaan antar perlakuan maka dilanjutkan dengan uji jarak berganda Duncan pada taraf 5\%. Penambahan tepung otak sapi pada pakan sebanyak $50 \mathrm{mg} \mathrm{kg}^{-1}$ induk memberikan pengaruh dominan sebaran telur pada ukuran 1,01-1,5 mm sebesar $60 \%$, diameter telur 0,90 $\mathrm{mm}$, dan fekunditas relatif sebesar 67 butir $\mathrm{g}^{-1}$.
\end{abstract}

Kata penting: diameter telur, fekunditas, ikan komet, sebaran telur, tepung otak sapi

\begin{abstract}
This study aimed to determine the effect of brain flour cow's on feed in the performance of eggs and fecundity in fish comet. The research was conducted at the Faculty of Fisheries and Marine Sciences, University of Padjadjaran at November 2014 until January 2015. Freeze-drying of bovine brains was conducted at the Inter Research Center University(PAU), Bandung Institute of Technology. The research was using Completely Randomized Design con-sisting of four treatments and three replications. The treatment were $20 \mathrm{mg} \mathrm{kg}^{-1}, 35 \mathrm{mg} \mathrm{kg}{ }^{-1}, 50 \mathrm{mg} \mathrm{kg}^{-1}$ and control. Parameters observed were the distribution of the eggs, egg diameter and fecundity using gravimetric methods. Data were analyzed using analysis of variance. If there are differences among the treatments then continued with Duncan's multiple range test at $5 \%$ level. Addition of bovine brain meal in feed with dose of $50 \mathrm{mg} \mathrm{kg}^{-1}$ was give a dominant influence on the size distribution of eggs by $60 \%$ from 1.01 to $1.5 \mathrm{~mm}$, egg diameter $0.90 \mathrm{~mm}$, and fecundity of 67 grains $\mathrm{g}^{-1}$.
\end{abstract}

Keywords: bovine brain meal, comet fish, egg diameter, eggs distribution, fecundity,

\section{Pendahuluan}

Ikan komet (Carassius auratus auratus) merupakan komoditas ikan hias dari jenis ikan mas koki (goldfish) yang memiliki permintaan yang cukup tinggi dan harga relatif stabil di pasaran. Tingginya permintaan terhadap produksi ikan komet, harus didukung oleh ketersediaan induk untuk mendapatkan benih dengan jumlah dan kualitas yang baik. Terutama pada musim ke-

$\triangle$ Penulis korespondensi

Alamat surel: usubfish@gmail.com marau, produktifitas induk yang matang gonad terganggu oleh interval suhu yang tinggi yaitu perbedaan suhu antara siang dan malam. Menurut Mananos et al. (2009) suhu merupakan faktor penting yang memengaruhi waktu pemijahan pada banyak spesies khususnya spesies di daerah tropik dan subtropik. Produksi telur bervariasi selama musim pemijahan sebagai dampak dari perubahan suhu (Kurita et al. 2011), ketersediaan pakan (Somarakis et al. 2006), komposisi ukuran ikan dan kondisi nutrisi induk (Scott et al. 2006). 
Faktor lingkungan dapat digunakan selama gametogenesis guna memanipulasi waktu pemijahan ikan untuk mendapatkan gamet yang layak sepanjang tahun (Chemineau et al. 2007). Berdasarkan fakta bahwa ikan yang dibudidayakan mengalami kegagalan pematangan gamet dan betina dikarenakan pelepasan Luteinizing Hormon (LH) yang berkurang dari kelenjar pituitari, maka hal ini memacu untuk melakukan manipulasi fungsi reproduksi dengan sediaan LH eksogen yang memengaruhi gonad secara langsung (Mylonas et al. 2010). Sediaan hormon luteinizing meliputi (a) ekstrak murni dari pituitari ikan dewasa selama musim reproduksi (paling umum ikan mas Cyprinus carpio dan salmon Oncorhynchus masou) yang mengandung jumlah LH yang tinggi, dan (b) Human Chorionic Gonadotropin (HCG) yang dimurnikan memiliki aktivitas LH sangat kuat (Mylonas et al. 2001)

Otak sapi merupakan sumber Gonadotropin Releasing Hormon (GnRH) alami yang dapat digunakan untuk mempercepat kematangan gonad ikan. Otak merupakan organ yang sangat penting dalam sistem reproduksi, karena pada setiap bagian otak terdapat GnRH yang tersusun atas 10 asam amino atau dekapeptida berfungsi untuk merangsang pelepasan gonadotropin $(\mathrm{GtH})$ dari kelenjar hipofisis (Subhan 2011). GtH berperan dalam dalam proses perkembangan gonad termasuk pertumbuhan oosit dan pematangan gonad, ovulasi, dan pemijahan (Bromage \& Robert 1995). Diameter telur komet siap pijah yaitu sebesar 0,92 $\pm 0,05 \mathrm{~mm}$. Indikator ikan siap pijah didasarkan pada kondisi posisi telur fase GVBD (Germinal Vesicle Breakdown) (Arfah et al. 2013). Pemberian otak sapi yang dibuat tepung dan dicampur pada pakan dapat dijadikan alternatif dalam merangsang perkembangan gonad ikan komet. Tujuan penelitian ini untuk menentukan dosis tepung otak sapi pada pakan yang ber- pengaruh terhadap performa telur dan fekunditas ikan komet

\section{Bahan dan metode}

\section{Bahan dan alat penelitian}

Penelitian dilaksanakan di panti benih Gedung Empat Fakultas Perikanan dan Ilmu Kelautan Universitas Padjadjaran pada bulan November 2014 sampai dengan Januari 2015. Bahan penelitian yang digunakan meliputi: induk ikan komet betina dengan bobot 9,67 - 12,22 g, tepung otak sapi hasil pengeringan dingin pada suhu dingin $-85^{\circ} \mathrm{C}$, pakan ikan berbentuk pellet dengan kadar protein 28\%, Binder Carboxymethyl cellulose (CMC), dan larutan sera.

Alat yang digunakan meliputi: akuarium ukuran $(60$ x $30 \times 30) \mathrm{cm}^{3}$, DO meter merk Lutron dengan ketelitian $0,01 \mathrm{mg} \mathrm{L^{-1 }}, \mathrm{pH}$ meter merk Lutron, termometer digital, blender, alat pencetak pelet, alat bedah, timbangan analitik, mikroskop, mikrometer, dan gelas obyek.

\section{Metode penelitian}

Metode penelitian menggunakan metode eksperimental dengan Rancangan Acak Lengkap dengan empat perlakuan dan tiga ulangan. Perlakuan dalam penelitian ini adalah pemberian dosis tepung otak sapi yang dicampur pada pakan komersial (kandungan protein 28\%). Varian dosis tepung otak sapi yang digunakan dalam penelitian ini didasarkan pada hasil pemberian otak ikan patin sebesar $250 \mathrm{mg}$ per $\mathrm{kg}$ induk (Subhan 2011) dan konsentrasi hipofisis sapi $0,6 \mathrm{ml} \mathrm{kg}^{-1}$ induk yang mampu merangsang pematangan gonad ikan lele dumbo, Clarias gariepinus Burchell 1822 (Setianto 2013). Penentuan pemberian tepung otak sapi tertinggi (50 mg per $\mathrm{kg}$ induk) pada penelitian ini didasarkan pada konsentrasi otak ikan patin $250 \mathrm{mg}$ yang berfungsi dalam merangsang pemijahan ikan lele dumbo. Otak 
sapi seberat $250 \mathrm{mg}$ setelah dibuat tepung dengan cara kering dingin menjadi $50 \mathrm{mg}$. Rincian leng-kap perlakuan sebagai berikut :

- Perlakuan $\mathrm{A}=$ pemberian pakan tanpa campuran tepung sapi (kontrol)

- Perlakuan $\mathrm{B}=$ pemberian pakan dengan campuran tepung otak sapi $20 \mathrm{mg} \mathrm{kg}^{-1}$ induk.

- Perlakuan $\mathrm{C}=$ pemberian pakan dengan campuran tepung otak sapi $35 \mathrm{mg} \mathrm{kg}^{-1}$ induk.

- Perlakuan $\mathrm{D}=$ pemberian pakan dengan campuran tepung otak sapi $50 \mathrm{mg} \mathrm{kg} \mathrm{kg}^{-1}$ induk.

\section{Prosedur penelitian}

Otak sapi segar ditepungkan dengan menggunakan metode beku kering (freeze dry). Hasil beku kering diblender halus lalu ditimbang kemudian disimpan dalam lemari pendingin. Pengambilan dosis tepung otak sapi didasarkan pada perhitungan perbandingan dengan penggunaan ekstrak otak sapi. Pakan uji terdiri atas campuran pakan komersial dan tepung otak sapi dengan komposisi sesuai dengan perlakuan. Sebagai perekat ditambahkan CMC sebanyak 3\%, dan dicetak kembali menjadi pelet.

Induk komet yang digunakan sebanyak 12 ekor setiap akuarium. Pemberian pakan untuk pemeliharaan induk ikan komet dilakukan dua kali sehari yaitu pada pukul 09.00, dan sore hari pada 15.00 selama dua bulan. Jumlah pakan yang diberikan yaitu 3\% dari bobot biomassa ikan. Pembersihan wadah pemeliharaan dilakukan dua hari sekali dengan cara penyiponan. Pemeriksaan kematangan gonad ikan komet dilakukan pada tiga waktu yang berbeda, yaitu (1) setelah pemeliharaan selama satu bulan, (2) setelah pemeliharaan selama $1 \frac{1}{2}$ bulan, dan (3) setelah pemeliharaan selama dua bulan. Bobot induk ikan komet terlebih dahulu ditimbang sebanyak lima ekor untuk setiap akuarium, kemudian tubuh induk dibedah untuk diambil gonadnya dan ditimbang.

\section{Pengukuran kualitas air}

Pengamatan kualitas air dilakukan untuk mengetahui faktor fisik dan kimiawi air yang berpengaruh terhadap pemeliharaan ikan komet selama penelitian. Adapun faktor fisik yang diamati yaitu suhu $\left({ }^{\circ} \mathrm{C}\right)$, sedangkan faktor kimiawi yang diamati meliputi $\mathrm{pH}$ dan oksigen terlarut. Pengukuran suhu dengan metode pemuaian masa air raksa yang terdapat dalam termometer. Metode pengukuran $\mathrm{pH}$ dan oksigen terlarut secara potensiometri dengan menggunakan $\mathrm{pH}$ meter dan DO meter merk Lutron. Pengamatan parameter air dilakukan sebanyak tiga kali yaitu pada awal, tengah, dan akhir penelitian.

\section{Parameter pengamatan}

Telur yang teramati diukur dengan menggunakan mikropipet dan diklasifikasikan sebaran ukurannya menjadi empat kelas, sebagai berikut :

$$
\begin{aligned}
& \text { - Kelas } 1 \text { : 0,01-0,5 mm } \\
& \text { - Kelas } 2 \text { : 0,51-1 mm } \\
& \text { - Kelas } 3 \text { : } \quad 1,01-1,5 \mathrm{~mm} \\
& \text { - Kelas } 4 \quad \text { : } \quad 1,51-2 \mathrm{~mm}
\end{aligned}
$$

Pengukuran diameter telur dilakukan dengan cara mengamati telur dibawah mikroskop binokuler dengan bantuan mikrometer okuler dengan ketelitian $0,1 \mathrm{~mm}$ yang telah ditera. Keseluruhan diameter telur yang teramati dicari nilai tengahnya dengan menggunakan rumus menurut Hemming \& Buddington (1988) sebagai berikut :

$$
\mathrm{X}_{\text {rata-rata }}=\sum \mathrm{X}_{\mathrm{i}} / \mathrm{n}
$$

Keterangan: $\mathrm{x}_{\mathrm{i}}=$ diameter telur yang diamati, $\mathrm{n}=$ jumlah telur yang diamati

Penghitungan fekunditas didasarkan pada fekunditas relatif yaitu jumlah telur ikan per bo- 
bot ikan mengikuti Kingdom \& Allison (2011). Untuk mendapatkan nilai fekunditas relatif, maka digunakan rumus di bawah ini:

$\mathrm{FR}=(\mathrm{n} . \mathrm{Wt} / \mathrm{Ws}) / \mathrm{BW}$

Keterangan: $F R=$ fekunditas relatif, $n=$ jumlah telur sampel (butir), $\mathrm{Wt}=$ berat gonad total yang ditimbang $(\mathrm{g}), \mathrm{Ws}=$ berat telur sampel yang ditimbang $(\mathrm{g}), \mathrm{BW}=$ bobot tubuh ikan tanpa gonad $(\mathrm{g})$

\section{Analisis data}

Data diameter telur dan fekunditas dianalisis menggunakan analisis keragaman dengan uji $\mathrm{F}$ untuk mengetahui pengaruh setiap perlakuan. Apabila terdapat perbedaan antarperlakuan maka dilanjutkan dengan uji jarak berganda Duncan pada taraf 5\% (Gasperz 1991). Sementara data sebaran ukuran telur dianalisis secara deskriptif.

\section{Hasil}

\section{Sebaran ukuran telur}

Berdasarkan hasil penelitian dapat terlihat perbedaan persentase ukuran telur dari hari pemeliharaan ke 30 sampai hari pemeliharaan ke 60 (Tabel 1). Pada waktu pemeliharaan hari ke 30 terlihat bahwa perlakuan $\mathrm{A}, \mathrm{B}$, dan $\mathrm{C}$ dominan telurnya masih berada pada ukuran 0,01-0,5 mm dan 0,51-1 $\mathrm{mm}$, berbeda dengan perlakuan $\mathrm{D}$ yang dominan sebaran telurnya berada pada ukuran 1,01-1,5 mm (61,67\%). Pada pemeliharaan hari ke 45 persentase telur pada perlakuan A, B, dan C masih dominan pada ukuran 0,01-0,5 $\mathrm{mm}$ dan $0,51-1 \mathrm{~mm}( \pm 50 \%)$, dan perlakuan $\mathrm{D}$ masih menunjukkan hasil terbaik dengan persentase telur dominan pada ukuran 1,01-1,5 mm (60\%). Berbeda dengan waktu pemeliharaan sebelumnya pada waktu pemeliharaan 60 hari persentase ukuran telur perlakuan A, C, dan D dominan pada ukuran 1,01-1,5 mm (55,56-61,67\%) dan perlakuan $\mathrm{B}$ tersebar merata pada ukuran 0,01-1,5 mm.

\section{Diameter telur}

Hasil penelitian menunjukkan bahwa nilai rata-rata diameter telur pada pemeliharaan hari ke 30 yaitu berkisar antara 0,67-0,95 mm (Tabel 2). Nilai diameter rata-rata telur tertinggi pada pemeliharaan hari ke 30 terdapat pada perlakuan D yaitu sebesar $0,95 \mathrm{~mm}$, sedangkan rata-rata diameter telur terendah pada pemeliharaan hari ke 30 terdapat pada perlakuan $C$ yaitu $0,67 \mathrm{~mm}$. Nilai rata-rata diameter telur pada pemeliharaan hari ke 45 yaitu berkisar antara 0,57-0,90 $\mathrm{mm}$. Nilai diameter rata-rata tertinggi pada pemeliharaan hari ke 45 terdapat pada perlakuan D yaitu 0,90 $\mathrm{mm}$, sedangkan rata-rata diameter telur terendah terdapat pada perlakuan B yaitu 0,57 mm. Nilai rata-rata diameter telur pada pemeliharaan hari ke 60 yaitu berkisar antara 0,78-1,10 $\mathrm{mm}$. Nilai diameter rata-rata tertinggi pada pemeliharaan hari ke 60 terdapat pada perlakuan $\mathrm{C}$ yaitu $1,10 \mathrm{~mm}$, sedangkan nilai rata-rata diameter telur terendah terdapat pada perlakuan B yaitu $0,78 \mathrm{~mm}$.

Tabel 1. Persentase sebaran telur induk ikan komet berdasarkan ukuran diameter

\begin{tabular}{cccccccccccccc}
\hline $\begin{array}{c}\text { Diameter } \\
(\mathrm{mm})\end{array}$ & \multicolumn{3}{c}{ Perlakuan A } & \multicolumn{3}{c}{ Perlakuan B } & \multicolumn{3}{c}{ Perlakuan C } & \multicolumn{3}{c}{ Perlakuan D } \\
\hline Hari ke & 30 & 45 & 60 & 30 & 45 & 60 & 30 & 45 & 60 & 30 & 45 & 60 \\
$0,01-0,5$ & 23,33 & 57,22 & 20,56 & 35,56 & 52,78 & 26,67 & 42,22 & 51,67 & 13,33 & 14,44 & 25,00 & 26,67 \\
$0,51-1$ & 21,67 & 14,44 & 18,89 & 13,33 & 20,56 & 32,22 & 25,56 & 6,67 & 10,56 & 20,00 & 11,67 & 7,22 \\
$1,01-1,5$ & 49,44 & 23,89 & 55,56 & 50,00 & 25,56 & 39,44 & 30,56 & 40,56 & 60,00 & 61,67 & 60,00 & 61,67 \\
$1,51-2$ & 5,56 & 4,44 & 5,00 & 1,11 & 1,11 & 1,67 & 1,67 & 1,11 & 16,11 & 3,89 & 3,33 & 4,44 \\
Total & 100 & 100 & 100 & 100 & 100 & 100 & 100 & 100 & 100 & 100 & 100 & 100 \\
\hline
\end{tabular}


Tabel 2. Rata-rata diameter telur induk ikan komet

\begin{tabular}{lccc}
\hline \multirow{2}{*}{ Perlakuan } & \multicolumn{3}{c}{ Diameter telur (mm) } \\
\cline { 2 - 4 } & Hari ke-30 & Hari ke-45 & Hari ke-60 \\
\hline A (kontrol) & $0,89 \pm 0,23 \mathrm{a}$ & $0,58 \pm 0,02 \mathrm{a}$ & $0,93 \pm 0,18 \mathrm{a}$ \\
$\mathrm{B}\left(20 \mathrm{mg} \mathrm{kg}^{-1}\right.$ induk $)$ & $0,75 \pm 0,53 \mathrm{a}$ & $0,57 \pm 0,10 \mathrm{a}$ & $0,78 \pm 0,18 \mathrm{a}$ \\
$\mathrm{C}\left(35 \mathrm{mg} \mathrm{kg}^{-1}\right.$ induk $)$ & $0,67 \pm 0,26 \mathrm{a}$ & $0,62 \pm 0,09 \mathrm{~b}$ & $1,10 \pm 0,20 \mathrm{a}$ \\
D (50 mg kg-1 induk) & $0,95 \pm 0,20 \mathrm{a}$ & $0,90 \pm 0,11 \mathrm{c}$ & $0,90 \pm 0,06 \mathrm{a}$ \\
\hline
\end{tabular}

Keterangan: Angka-angka yang diikuti oleh huruf kecil yang sama berarti tidak berbeda nyata pada taraf kepercayaan $95 \%$

Hasil analisis sidik ragam pada pemeliharaan hari ke 30 tidak menunjukkan perbedaan yang nyata antarperlakuan, namun memasuki hari pemeliharaan hari ke 45 analisis sidik ragam menunjukkan bahwa pemberian tepung otak sapi memberikan pengaruh yang nyata terhadap diameter telur ikan komet (Tabel 2). Berdasarkan hasil uji Duncan terlihat bahwa perlakuan A tidak berbeda nyata dengan perlakuan B tetapi berbeda nyata dengan perlakuan $\mathrm{C}$ dan D (Tabel 2). Perlakuan $\mathrm{D}$ memiliki nilai tertinggi $(0,90$ $\pm 0,11)$ dan berbeda nyata dengan perlakuan lainnya. Pada hari ke 60 lama pemeliharaan, diameter telur pada setiap perlakuan mempunyai ukuran yang tidak berbeda nyata.

\section{Fekunditas relatif}

Nilai fekunditas relatif ikan komet pada penelitian ini bervariasi besarannya di setiap pengamatan. Hasil pengamatan pada hari ke 30 menunjukkan fekunditas relatif ikan komet berkisar antara 45-96 butir $\mathrm{g}^{-1}$, pada hari ke 45 berkisar antara 48-76 butir $\mathrm{g}^{-1}$ dan pada pengamatan hari ke 60 berkisar antara 21-67 butir $\mathrm{g}^{-1}$ (Gambar 1). Berdasarkan hasil analisis sidik ragam nilai fekunditas relatif pada ikan komet pada setiap pengamatan tidak berbeda nyata antarperlakuan.
Berdasarkan hasil pengukuran parameter kualitas air selama pemeliharaan ikan didapat kisaran kualitas air yang masih dalam toleransi untuk sintasan dan perkembangan gonad ikan komet. Suhu air pemeliharaan selama penelitian berkisar antara $26-28^{\circ} \mathrm{C}, \mathrm{pH}$ antara $7-8,5$ dan kandungan oksigen terlarut berkisar antara 4,0$5,4 \mathrm{mg} \mathrm{L}^{-1}$.

\section{Pembahasan}

\section{Sebaran ukuran telur}

Ukuran telur ikan sangat penting untuk diketahui dalam budi daya karena telur yang besar akan menghasilkan larva yang besar (Purdom 1993). Peningkatan ukuran diameter telur disebabkan oleh proses vitelogenesis. Vitelogenesis adalah proses penimbunan atau akumulasi kuning telur yang menyebabkan oosit pada fase pematangan kedua. Pada keadaan ini telur dalam tahap oosit sekunder dan dapat terlihat dengan ukuran beraneka ragam. Oosit yang telah tumbuh penuh memiliki satu nukleus GV (Germinal Vesicle) yang terletak di tengah oosit. Fenomena yang kali pertama dilihat dalam pematangan oosit akhir adalah pergerakan GV ke kutub anima, kemudian membran pecah dan terjadi GVBD atau Germinal Vesicle Breakdown 


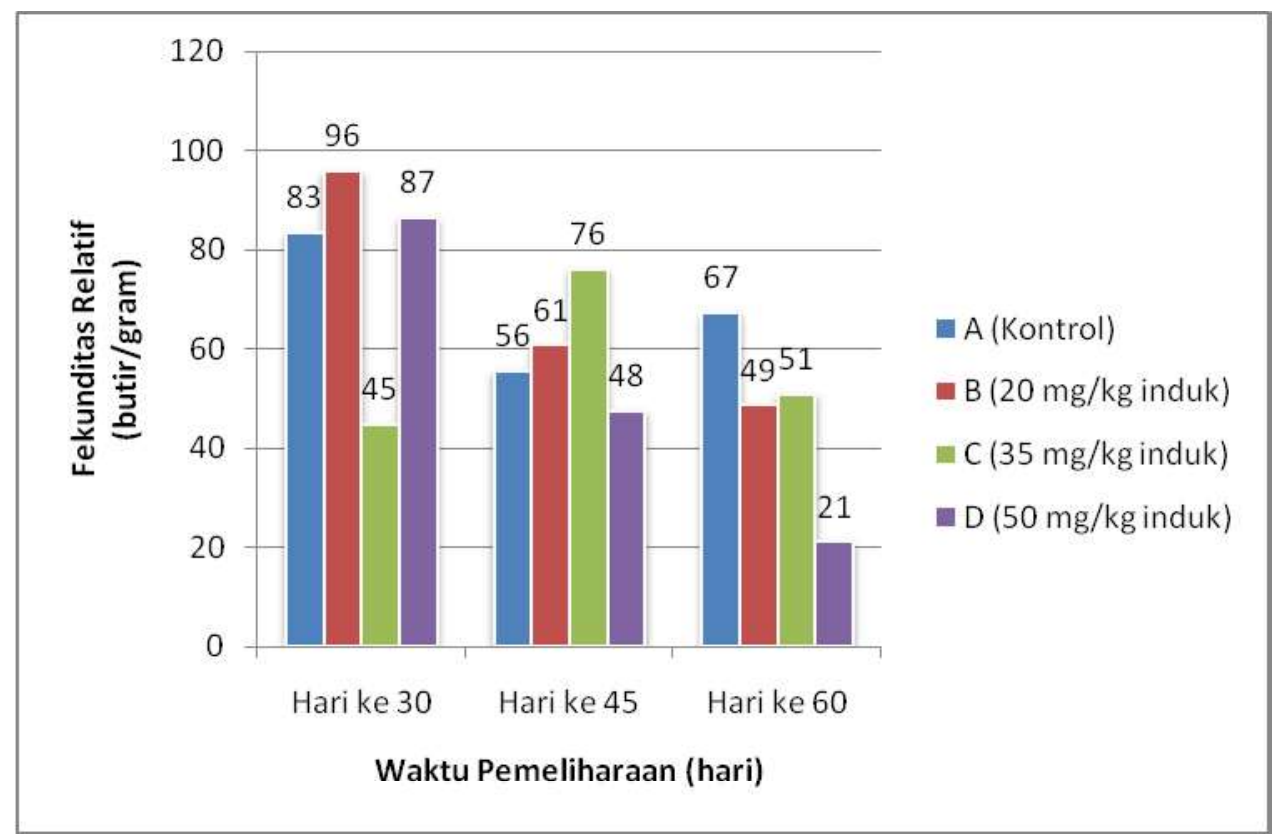

Gambar 1. Fekunditas relatif ikan komet

(Yaron \& Levavi-Sivan 2011, Mylonas et al. 2010, Nagahama et al. 1995). Menurut Najim et al. (2012) kisaran normal diameter telur ikan komet yaitu 0,3-1,00 mm, jika dibandingkan dengan hasil penelitian ini pada pemeliharaan hari ke 60 telur induk ikan komet dominan pada ukuran 1,01-1,5 mm sekitar $60 \%$ di atas ukuran normal. Hal ini membuktikan bahwa penambahan tepung otak sapi pada pakan dapat memengaruhi perkembangan ukuran telur pada induk ikan komet. GnRH pada tepung otak sapi merangsang kelenjar hipofisis untuk mengelurkan hormon LH yang berperan dalam merangsang proses pembentukan hormon steroid (estradiol). Hormon ini berfungsi untuk meningkatkan proses sintesis vitelogenin, sehingga pembentukan vitelin (jumlah dan ukuran) meningkat. Menurut Bromage \& Robert (1995) telur yang berukuran lebih besar dapat menghasilkan kualitas larva dan yuwana (fase yang sudah melewati larva, ketika organ tubuh sudah terbentuk sempurna seperti fase dewasa) yang berkualitas.

\section{Diameter telur}

Diameter telur merupakan garis tengah atau ukuran panjang suatu telur yang diukur dengan mikrometer berskala yang sudah ditera. Besar kecilnya diameter telur berkaitan dengan kualitas telur. Sebaran ukuran telur dan diameter telur menjadi indikator penting dalam menentukan kualitas kematangan telur (Bromage \& Robert 1995, Mylonas et al. 2010).

Ukuran diameter telur pada setiap perlakuan mempunyai pola perubahan diameter yang sama. Pada hari ke 45 terjadi penurunan diameter telur pada setiap perlakuan, dan meningkat kembali pada hari ke 60. Hal ini dikarenakan kondisi induk dari hari ke 30 sampai 45 hari mengalami stress, dampak dari serangan Argulus sp. yang menyebabkan tubuh induk mengalami bercak merah. Pada kondisi stress, pertumbuhan gonad ikan terganggu karena aliran energi untuk perkembangan gonad tidak berjalan dengan baik dan adanya energi yang digunakan untuk merespons stress lingkungan. Pada hari ke- 60 gonad kembali berkembang dengan baik, hal ini karena 
stress lingkungan (serangan parasit) dapat ditekan dan aliran energi dari pakan dan pemberian tepung otak sapi berpengaruh terhadap diameter telur. Pada pemberian tepuk otak sapi sebanyak $35 \mathrm{mg}$ per $\mathrm{kg}$ induk menunjukkan diameter telur yang tinggi dibandingkan dengan perlakuan lainnya. Dengan demikian GnRH yang ada pada tepung otak sapi berpengaruh terhadap diameter telur.

Menurut Selman et al. (1993), peningkatan diameter telur ini disebabkan terjadinya penyerapan lumen ovari akibat rangsangan hormonal yang sesuai. Pertambahan tersebut disebabkan energi yang terdapat di dalam tubuh induk ikan yang sangat erat kaitannya dengan suplai makanan, ukuran tubuh ikan, serta umur ikan tersebut (Effendie 1997). Nilai diameter telur perlakuan D tidak terjadi perubahan seperti yang telah dijelaskan sebelumnya; ini diduga ikan pada perlakuan D mengalami atresia yaitu penyerapan kembali telur-telur yang telah mencapai perkembangan maksimal namun tidak diovulasikan (Mylonas et al. 2013).

\section{Fekunditas relatif}

Banyaknya jumlah telur yang terdapat pada pemeliharaan hari ke 30 (berkisar antara 45 - 96 butir $\mathrm{g}^{-1}$ induk) dapat disebabkan oleh telur yang masih berukuran kecil dengan ukuran telur sekitar 0,05-0,15 $\mathrm{mm}$ yang berada dibawah rata-rata diameter telur ikan komet, hal ini juga menandakan bahwa pada waktu pemeliharaan hari ke 30 telur belum benar-benar matang (fase vitelogenesis) (Gambar 2a). Berbeda pada hari ke 45 dan 60 , telur sudah nampak besar dan jelas yang berarti pemberian pakan dengan campuran tepung otak sapi yang mengandung hormon $\mathrm{GnRH}$ memberikan pengaruh pada diameter telur ikan (Gambar 2b dan 2c). Hormon GnRH eksogen yang diberikan akan dibawa oleh reseptor $\mathrm{GnRH}$ menuju organ target (hipofisis) dengan tujuan untuk merangsang hipofisis mengeluarkan follicle stimulating Hormone (FSH). Hormon ini berfungsi merangsang pelepasan hormon steroid (estradiol) pada gonad (Elakkanai et al. 2015) yang selanjutnya memengaruhi sintesis pembentukan kuning telur pada vitelogenesis di hati. Semakin banyak vitelogenin yang dibawa ke gonad, maka semakin banyak butir-butir telur yang dibentuk dalam gonad (Arfah et al. 2013).

Berdasarkan hasil yang didapatkan, nilai fekunditas relatif pada perlakuan D mengalami penurunan pada pemeliharaan hari ke 60 , ini bisa dikaitkan dengan hasil diameter telur dan tingkat kematangan telur. Rata-rata fekunditas relatif pada pengamatan hari ke 60 mengalami penurunan menandakan bahwa ukuran telur ikan komet mengalami pembesaran dan juga proses atresia, sehingga jumlah telur berkurang karena telur yang sudah matang terserap kembali oleh tubuh ikan. Telur yang berukuran besar menandakan bahwa telur tersebut semakin matang seperti yang terlihat pada hasil tingkat kematangan telur pada hari pemeliharaan ke 60 . Berdasarkan hasil penelitian nilai fekunditas relatif ikan komet pada pemeliharaan hari ke 60 menunjukkan kisaran antara 21-67 butir $g^{-1}$. Hal ini sesuai dengan pernyataan Arfah et al. (2013) bahwa fekunditas relatif ikan komet sebesar 30-56 butir $\mathrm{g}^{-1}$ dan pernyataan Ortega-Salas \& Reyes-Bustamante (2006) bahwa rata-rata fekunditas relatif ikan Carasius auratus adalah 63 telur $\mathrm{g}^{-1}$. 

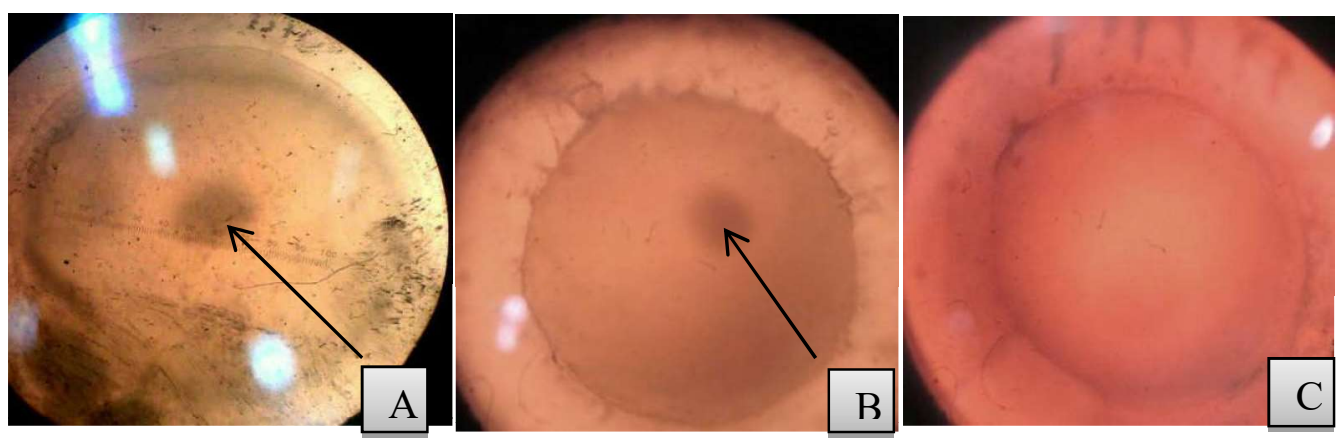

Gambar 2. Fase pergerakan inti telur ikan komet pada perlakuan D. (A) hari ke 30, posisi inti telur di tengah; (B) hari ke 45, posisi inti telur di tepi ; (C) hari ke 60, posisi inti telur melebur

Berdasarkan uraian di atas, maka penelitian tepung otak sapi hasil pengeringan dingin dapat dilanjutkan dengan pemberian jumlah yang lebih tinggi dari $50 \mathrm{mg} \mathrm{kg}^{-1}$ induk. Hal ini dikarenakan perlakuan $50 \mathrm{mg} \mathrm{kg}^{-1}$ merupakan perlakuan batas tinggi pada penelitian ini yang memberikan nilai pematangan terbaik, sehingga masih perlu dike-tahui jumlah pemberian tepung otak sapi yang lebih tinggi terhadap perporma reproduksi ikan komet. Selain itu perlu diketahui kandungan hormon GnRH yang lebih akurat untuk penentuan jumlah pemberian yang lebih tepat. Karena kelebihan pemberian hormon GnRH dapat menyebabkan stress dan menghambat proses pematangan (Garcia 1993) serta menjadi tidak efektif pada proses ovulasi telur (Alcántar-Vázquez et al. 2016).

Suhu air pemeliharaan selama penelitian berkisar antara $26-28^{\circ} \mathrm{C}, \mathrm{pH}$ berkisar antara $7-8,5$ dan oksigen terlarut. Berdasarkan hasil pengukuran parameter kualitas air selama pemeliharaan ikan didapat kisaran kualitas air yang masih dalam toleransi untuk sintasan dan perkembangan gonad ikan komet (Habib et al. 2014).

\section{Simpulan}

Penambahan tepung otak sapi pada pakan sebanyak $50 \mathrm{mg} \mathrm{kg}^{-1}$ induk memberikan penga- ruh terbaik hingga pemeliharaan hari ke 45 terhadap performa reproduksi ikan komet, dimana tercapai dominan sebaran telur pada ukuran 1,011,5 $\mathrm{mm}$ sebesar $60 \%$, diameter telur $0,90 \mathrm{~mm}$ dan fekunditas relatif sebesar 76 butir $\mathrm{g}^{-1}$.

Berdasarkan hasil penelitian, maka penggunaan tepuk otak sapi ( hasil pengeringan dingin) sebagai sumber GnRH alami sebanyak 50 mg. $\mathrm{kg}^{-1}$ induk dapat dijadikan solusi untuk meningkatkan performa reproduksi ikan komet.

\section{Daftar pustaka}

Alcántar-Vázquez JP, Pliego-Cortés HS, Dumas $\mathrm{S}$, Peña-Martínez R, Rosales-Velázquez $\mathrm{M}$, Pintos-Terán P. 2016. Effects of a luteinizing hormone-releasing hormone analogue (LHRHa) on the reproductive performance of spotted sand bass Paralabrax maculatofasciatus (Percoidei: Serranidae). Latin American Journal of Aquatic Research, 44(3): 487-496.

Arfah H, Melati, Setiawati M. 2013. Suplementasi vitamin E dengan dosis berbeda pada pakan terhadap kinerja reproduksi induk betina ikan komet (Carassius auratus auratus), Jurnal Akuakultur Indonesia, 12(1): 14-18.

Bromage RN, Roberts RJ. 1995. Broodstock Management and Egg Larval Quality. Blackwell Science. Oxford. 436 p.

Chemineau P, Malpaux B, Brillard JP, Fostier A. 2007. Seasonality of reproduction and production in farm fishes, birds and mammals. Animal 1(3): 419-432. 
Effendie MI. 1997. Biologi Perikanan. Yayasan Pustaka Nusatama, Yogyakarta. 159 hlm.

Elakkanai P, Francis T, Ahilan B, Jawahar P, Padmavathy P, Jayakumar N, Subburaj A. 2015. Role of GnRH, HCG and Kisspeptin on reproduction of fishes. Indian Journal of Science and Technology, 8(17): 1-10

Garcia LMB. 1993. Sustained production of milt in rabbitfish, Siganus guttatus Bloch, by weekly injection of luteinizing hormonereleasing hormone analogue (LHRHa). Aquaculture, 113(3): 261-267.

Gasperz V. 1991. Metode Perancangan Percobaan. Bandung:Armico. $471 \mathrm{hlm}$.

Habib MA, Sharker Md R, Rahman Md M, Ahan Md E, Pattadar SN 2014. Effects of feeding frequency on growth and survival in fry of gold fish, Carassius auratus (Hamilton) in outdoor rearing system. International Journal of Fisheries and Aquatic Studies, 1(4): 97-102

Heming TA, Buddington RK. 1988. Yolk absorption in embryonic and larval fishes. In: Hoar WS, Randall DJ. Fish Physiology volume 9 The Physiology of Developing Fish Part A Eggs and Larvae. Academic Press, San Diego, CA. pp. 407-446.

Kingdom T, Allison ME. 2011. The fecundity, gonadosomatic and hepatosomatic indices of Pellonula leonensis in the Lower Nun River, Niger Delta, Nigeria. Current Research Journal of Biological Sciences, 3(2): 175179.

Kurita Y, Fujinami F, Amano M. 2011. The effect of temperature on the duration of spawning markers - migratory-nucleus and hydrated oocytes and postovulatory follicles in the multiple-batch spawner Japanese flounder (Paralichthys olivaceus) Fishery Bulletin, 109(1): 79-89.

Mañanós E, Duncan N, Mylonas C. 2009. Reproduction and control of ovulation, spermiation and spawning in cultured fish. In: Cabrita E, Robles V, Herráez P (eds.). Methods in Reproductive Aquaculture Marine and Freshwater Species, CRC Press, Boca Raton. pp. 3-80.

Mylonas CC, Zohar Y. 2001. Use of GnRHadelivery systems for the control of reproduction in fish. Reviews in Fish Biology and Fisheries, 10(4): 463-491.
Mylonas CC, Fostier A, Zanuy S. 2010. Broodstock management and hormonal manipulations of fish reproduction. General and Comparative Endocrinology, 165(3): 516534

Mylonas CC, Mitrizakis N, Castaldo C, Cerviño C, Papadaki M, Sigelaki I. 2013. Reproduction of hatchery-produced meagre Argyrosomus regius in captivity II. Hormonal induction of spawning and monitoring of spawning kinetics, egg production and egg quality. Aquaculture 414-415: 318-327

Nagahama Y, Yoshikuni M, Yamashita M, Tokumoto T, Katsu Y. 1995. Regulation of oocyte growth and maturation in fish. In: Roger A. Pedersen RA, Schatten GP (Eds.). Current Topics in Developmental Biology. Vol. 30. Academic Press, San Diego. pp. 103-145

Najim S, Almudhaffar RAA, Jassim FK. 2012. Some reproductive character of the fantail goldfish (Carassius auratus auratus) female from rearing pond in Basrah, southern Iraq. Iraqi Journal of Aquaculture 9(1): 83-94

Ortega-Salas AA, Reyes-Bustamante H. 2006. Initial sexual maturity and fecundity of the goldfish (Carassius auratus) (Perciformes: Cyprinidae) under semi-controlled conditions. Revista de Biologia Tropical, 54(4): 1113-1116

Purdom, C.E. 1993. Genetics and Fish Breeding. Ministry of Agriculture, Fisheries and Food. Fisheries Laboratory. Lowestoff. Suffolk. UK. $277 \mathrm{p}$

Scott BE, Marteinsdottir G, Begg GA, Wright P J, Kjesbu OS. 2006. Effects of population size/age structure, condition and temporal dynamics of spawning on reproductive output in Atlantic cod (Gadus morhua). Ecological Modelling, 191(3-4): 383-415.

Selman K, Wallace RA, Sarka A, Qi X. 1993. Stages of oocyte development in the zebrafish, Brachydanio rerio. Journal of Morphology, 218(2): 203-224.

Setianto A. 2013. Efektifitas ekstrak hipofisa sapi dalam merangsang kematangan gonad ikan lele dumbo (Clarias gariepinus). Skripsi. Fakultas Perikanan dan Ilmu Kelautan. Universitas Padjadjaran. Jatinangor.

Somarakis S, Ganias K, Siapatis A, Koutsikopoulos C, Machias A, Papaconstantenou C. 2006. Spawning habitat and daily egg production of sardine (Sardina pilchardus) in 
the eastern Mediterranean. Fisheries Oceanography, 15(4): 281-292.

Subhan, U. 2011. Evaluasi efektifitas ekstrak otak ikan patin dalam menginduksi pemijahan ikan lele sangkuriang, Clarias sp. Tesis. Sekolah Pascasarjana Institut Pertanian Bogor, Bogor. 77 hlm.
Yaron Z, Levavi-Sivan B. 2011. Endocrine regulation of fish reproduction. In: Farrell AP (ed.). Encyclopedia of Fish Physiology: From Genome to Environment, volume 2. Academic Press, San Diego. pp. 1500-1508 